\title{
Reclaimed water to face agricultural water scarcity in the Mediterranean area: An overview using SDG preliminary data
}

\author{
Giuseppe Mancuso ${ }^{a, b^{*}}$, Stevo Lavrnić ${ }^{a}$, Attilio Toscano ${ }^{a}$ \\ ${ }^{a}$ Department of Agricultural and Food Sciences, Alma Mater Studiorum - University of \\ Bologna, viale Giuseppe Fanin 50, Bologna, 40127, Italy \\ ${ }^{\mathrm{b}} \mathrm{CIRI}$ FRAME - Interdepartmental Centre for Industrial Research in Renewable Resources, \\ Environment, Sea and Energy, Alma Mater Studiorum - University of Bologna, Via Selmi 2, \\ Bologna, 40126, Italy \\ * Corresponding author. Tel. +390512096182 \\ E-mail addresses: g.mancuso@unibo.it (G. Mancuso), stevo.lavrnic@unibo.it (S. Lavrnić), \\ attilio.toscano@unibo.it (A. Toscano)
}

\section{Abstract}

Climate change is exacerbating the existing water scarcity issue in the Mediterranean area, leading to unprecedented pressure on water supply, especially in arid regions. Current changes and future scenarios all indicate significant and increasing water demand during the coming decades. Water demand is further aggravated by the population growth, which consequently increases demand for crops and agricultural products. The use of reclaimed water (RW) seems to be a promising alternative and valuable water resource, particularly for agriculture, which is currently the main user of renewable water resources. In addition to preserving freshwaters, the use of RW for irrigation would represent a source of nutrients, namely nitrogen, phosphorus, and other salts, which are necessary for the physiological growth of crops. For the Mediterranean area, it was possible to investigate on the significance of the RW use through the comparison of different data such as the total amount of generated wastewater, which represents the potential of using RW as an irrigation source, and irrigation water requirement, respectively. The analysis showed that the use of RW could significantly decrease the current pressure on total renewable water resources, and therefore help to face water scarcity and climate change issues. Nevertheless, for the Mediterranean area, there are still limiting elements such as the non-existence of a univocal regulatory framework on the use of RW for irrigation purposes as well as a lack of data on real quantities of wastewater that are safely treated, collected and generated. 


\section{Keywords}

Water scarcity; Climate change; Reclaimed water; Water reuse; Wastewater.

\begin{tabular}{|c|c|c|}
\hline AEAI & $=$ & Area Equipped for Full Control Irrigation: Actually Irrigated \\
\hline AET & $=$ & Area Equipped for Full Control Irrigation: Total \\
\hline AOPs & $=$ & Agricultural Water Withdrawals \\
\hline AWW & $=$ & Advanced Oxidation Processes \\
\hline BATs & $=$ & Best Available Technologies \\
\hline CA & $=$ & Cultivated Area \\
\hline CWW & $=$ & Collected Wastewater \\
\hline DR & $=$ & Dependency Ratio \\
\hline EEA & $=$ & European Environmental Agency \\
\hline EU & $=$ & European Union \\
\hline FAO & $=$ & Food and Agriculture Organization \\
\hline GWW & $=$ & Generated Wastewater \\
\hline IWR & $=$ & Irrigation Water Requirement \\
\hline MDG & $=$ & Millennium Development Goal \\
\hline MDG 7.5 & $=$ & Millennium Development Goal Indicator 7.5 \\
\hline $\mathrm{P}$ & $=$ & Population \\
\hline RW & $=$ & Reclaimed water \\
\hline SDGs & $=$ & Sustainable Development Goals \\
\hline SDG 6.4.2. WS & $=$ & Sustainable Development Goal 6.4.2. Water Stress Indicator \\
\hline STWW & $=$ & Safely Treated Wastewater \\
\hline TRWR & $=$ & Total Renewable Water Resources \\
\hline TWW & $=$ & Total Water Withdrawals \\
\hline UN & $=$ & United Nations \\
\hline WHO & $=$ & World Health Organization \\
\hline WEI & $=$ & Water Exploitation Index \\
\hline WS & $=$ & Water Supply \\
\hline WSI & $=$ & Water Scarcity Indicator \\
\hline WWTPs & $=$ & Wastewater Treatment Plants \\
\hline
\end{tabular}




\section{Introduction}

Water is a valuable resource that has been increasingly used for commercial, industrial, domestic, public supply, irrigation, livestock, mining, and thermoelectric power purposes worldwide. Nowadays, it is a limited source, especially for Mediterranean countries that are presently experiencing water stress [1-3]. Water resources are not equally distributed in space and time [4], and they are currently under pressure due to human activities and economic development. The progressive population growth has led, on the one hand, to an intensification of urbanization and to an expansion of both water supply and sanitation systems [5]; on the other hand, it has caused an increase in the global food production in order to meet the demand of a growing population [6]. This has resulted in in an increased water demand. Furthermore, different climate change scenarios have projected temporal and spatial variation of dynamics associated with the hydrologic cycle, further aggravating the already existing discrepancies between water supply and water demand. In addition to water scarcity issues, industrial development has also led to the pollution of uncontaminated water resources, affecting their quality and, thus, limiting their use [7]. If this situation is not remedied soon, this trend will make the availability of water in sufficient quantity and quality even more of a worldwide challenge in the future, and especially in the Mediterranean area.

Within this context, different countries are exploring ways of using the so called "non-conventional" waters, mostly desalination of seawater or highly brackish groundwater and the use of treated wastewater from urban and rural settlements. The use of RW has been increasingly practised in the last years across the world, especially in arid or semi-arid areas [8], where it is necessary to preserve and use more effectively the available water resources. Furthermore, it is now widely recognised that global climate changes are progressively aggravating water shortages, resulting in a progressively unpredictable supply [9]. Generally, the use of RW can be intended as i) direct potable use, ii) indirect potable use, and iii) use for non-drinking purposes including agriculture irrigation [10]. It has been estimated that agriculture accounts for over $70 \%$ of global freshwater withdrawals [11], and therefore irrigation by means of RW would have the potential to preserve freshwater resources by avoiding their abstraction, reducing the usage of drinking water for non-potable purposes. In addition to the mentioned benefits, the use of RW might be an effective-cost and energy-safe strategy for wastewater treatment, due to the recovery of valuable nutrients from the treated wastewater [12], playing thus a key role in satisfying the main criteria for a Circular Economy strategy [13].

Therefore, the use of RW is increasingly practiced in Mediterranean countries, which appear very vulnerable to climate global change, with multiple potential impacts due to reduced precipitation and increased temperatures [14-16]. However, social acceptance for the use of RW is a goal to be fully achieved [17]. 
Nevertheless, different attempts have been made by international organizations worldwide (i.e. World Health Organization (WHO) [18], United Nations Environment Programme (UNEP) [19,20], United Nations Water Decade Programme on Capacity Development (UNW-DPC) [21], International Organization for Standardization (ISO) [22] and Food and Agriculture Organization (FAO) [23]) to develop guidelines and regulations for the safe use of RW in agriculture. That way, they could ensure a safe practice and prevent risks for public health due to RW microbiological content, at the same time protecting the environment from the introduction of hazardous contaminants.

However, the main institutions of different countries are still working on the development of legislations for the direct use of RW for irrigation and aquifer recharge purposes. For instance, the European Parliament has recently approved a new legislation defining minimum requirements at European level for the safe use of RW for agricultural purposes, ensuring people and environment protection [24].

An appropriate legislation should lead to high quality levels of RW through the application and the combination of novel or already existing technologies available for the tertiary treatment (Best Available Technologies (BATs) [25] as defined in the Industrial Emissions Directive (IED)), guaranteeing the fulfilling of high-water quality standards. With this main aim, the most implemented tertiary methods such as physical, chemical and biological treatments $[26,27]$ can be exploited to increase the removal efficiencies of total suspended/dissolved solids, nutrients, microbial pathogens, heavy metals, pharmaceuticals or other contaminants of emerging concern (i.e. microplastics, hydrocarbons, pesticides, etc.).

In this chapter, the effects of climate change and population growth on water resources have been critically discussed focusing on the Mediterranean area. For each Mediterranean country, a detailed analysis of the agricultural pressure on renewable water resources and the potential associated with the RW use to cope with this pressure has been provided. As Mediterranean countries have been chosen all of those that have direct approach to the Mediterranean Sea. From the total amount of 23, 20 countries have been reviewed in detail. Less attention has been given to Gibraltar, Monaco, and Montenegro due to their small size, lack of independent water resources or lack of data on renewable water and wastewater resources. FAO data from the AQUASTAT database have been exploited to estimate the quantity of freshwaters used for irrigation purposes, whereas recent SDG data on safely treated, generated and collected wastewater have been used to investigate the potential use of RW to meet agricultural water needs. Furthermore, a brief overview of guidelines and regulations on the use of RW in the Mediterranean countries has been provided, highlighting the barriers and the potential of using RW to cope with the issues related to water scarcity and climate change. 


\section{Effects of climate change and population growth on water resources}

The total amount of water available in the Mediterranean area will be reduced as a consequence of three main factors: (i) temperature increase, (ii) precipitation decrease, and (iii) population growth [28], particularly in the countries already with limited renewable water resources [29].

\subsection{Global land surface air temperature anomalies}

Land surface air temperature is rising up at an unprecedented pace since the past century [30]. This warming is not temporally and spatially characterized by uniformity, and its evolution may irreversibly affect the hydrological cycle and the terrestrial environment in general. The distribution of mean temperature anomalies for each season has shifted toward higher temperatures and the range of anomalies has raised up (Fig. 1). As it is well known, when solar radiation reaches the Earth's atmosphere, it is partially absorbed by the land and the oceans, while the rest is reflected back into the space. Some of this energy is trapped by greenhouse gases in the atmosphere, keeping the Earth warm enough to sustain life. However, recent human activities have increased the amount of greenhouse gases released into the atmosphere (carbon dioxide, nitrous oxide, methane, and others), causing a progressive increase in global land surface air temperature. Water resources are strongly vulnerable to climate change and climate variability. Among the potential climate risks for water resources are included the reduced groundwater recharge and supplies, the seawater intrusion to coastal aquifers, the reduction of freshwater availability, and the increased demand from communities and industries. Moreover, higher global land surface air temperatures may increase the risk, among the others, of bacterial contamination in water supplies [31], blue-green algal outbreaks [32] and acid-sulphate soil [33] issues.

\subsection{Global precipitation}

An increase in the average global temperature is very likely to lead to further changes in intensity, duration, frequency and amount of precipitation events, implying a strong variability in space and time of their distributions, especially in the Mediterranean area (Fig. 2). Precipitation strongly depends on atmosphere moisture: the water vapour, which feeds precipitation, originates from two main sources represented by the evapotranspiration of oceans (about $60 \%$ of the total amount) and other water resources in the inland (the remaining 40\%). As the atmosphere gets warmer, it is able to hold more moisture, leading to an increase in the intensity of downpours and, then, rising up the risk of extreme events such as floods, which depend in part on how much water can be held by the air at a given time. While a steady moderate precipitation soaks into the soil and benefits the plants, the same amount of rainfalls in a shorter period of time might may cause local flooding and run-off, leaving the soil much drier at the end of a single day. Floods are therefore associated with extremes in rainfall, whereas the opposite consequence due to climate change could be identify with a lack of precipitation and often 
extremely high temperatures that can contribute to drying the soil. These drought phenomena are further aggravated by higher values of evapotranspiration that can be detected under higher air temperatures, thereby increasing the intensity and duration of drought. While flood events are often in a local scale and are usually characterized by a short duration, droughts are extensive and might last over months or even years. In order to cope with issues related with droughts, in the field of agriculture, irrigation has been used as a mitigation approach, resulting however in a further stress for the already limited water resources. Questioning about the future, different attempts have been made by many researchers worldwide in order to develop mathematical models to predict the effects due to climate change on precipitation and, thus, on water scarcity [34,35]. As expected, their findings confirmed a trend towards reduced rainfall in coming decades, resulting in a worsening of the current situation for water resources.

\subsection{Mediterranean population analysis}

As shown in Fig. 3, population in the Mediterranean area in the 1950s was around 200 million people, while it was currently estimated to be about 500 million people [28]. The Mediterranean population continues to grow, and it is expected to reach even higher values by 2100 . In this context, the consequent increase of water demand has to cope with already scarce water resources in the Mediterranean area, resulting in a lack of water to satisfy the constantly growing demand. The population growth and the progressive movement of people from rural areas to cities has increased the urbanization phenomena, which on the one hand have led to an increased pressure on freshwater resources, while on the other hand has strongly modified the hydrological cycle since natural landscapes were transformed into urban water-impervious lands. The population growth will lead to an increase in water use and withdrawals for personal (mainly drinking and hygiene), industrial and agricultural (namely irrigation) purposes. Also, the more the population grows, the higher is the amount of food required by the population. However, to produce more food, the agricultural sector needs to increase its production rates, resulting in an increased water use. Therefore, agricultural productivity and population growth are closely interrelated, and both may cause issues of water scarcity and hunger. In order to meet this ever-increasing water demand in the Mediterranean area, groundwater is being extensively used to supplement the available surface water or as a source of drinking water. Also, in situations of groundwater resources in areas bordering seas such as for the Mediterranean basin, coastal aquifers became a very important source of freshwater. However, the over abstraction from groundwater and the consequent lowering of their hydraulic levels, due to an intensive water demand by higher population densities of coastal zones, will make these water resources particularly susceptible to degradation due to saltwater intrusion. The population growth, thus, may lead to more restricted access to water in certain regions of the Mediterranean area. For these reasons, an integrated water 
resource management approach should give priority to water supplies that directly affect people's lives and ensure their welfare in an equitable manner, without compromising the sustainability of the global ecosystems.

\section{Availability of renewable water resources and agricultural water withdrawals in the Mediterranean area \\ In this section, the influence of withdrawals on total renewable water resources (TRWR) will be} evaluated in the Mediterranean area as well as the overall contribution of agriculture on total withdrawals.

\subsection{Total renewable water resources}

TRWR represent the maximum theoretical yearly amount of renewable water available per inhabitant of a country at a given moment [36]. Fig. 4 shows a comprehensive picture of the TRWR per inhabitant $\left(\mathrm{m}^{3}\right.$ year $\left.^{-1}\right)$ in the Mediterranean area in the 2019 [36]. As shown in Fig. 4, water resources are not equally distributed in space. The distribution of water resources is mainly conditioned by the distribution of rainfall, which is not uniform worldwide (Fig. 2). From Fig. 4 and according to the water barrier differentiation proposed by Falkenmark [37], it can be observed that some of the countries, namely in the southern Mediterranean, fall into the categories under the threshold value of $1,700 \mathrm{~m}^{3}$ capita $^{-1}$ year $^{-1}$, confirming that those countries are currently experiencing water stress and absolute water scarcity. Countries such as France, Italy, Spain, and Turkey are not experiencing a situation of chronic or absolute water scarcity, but the presence of occasional or permanent local water stress is a serious concern that cannot be underestimated. On the contrary, values higher than 5,000 $\mathrm{m}^{3} \mathrm{capita}^{-1}$ $y^{\text {year }}{ }^{-1}$ for countries located in the North-West part of the Mediterranean basin indicate that there are abundant water resources nationally, and thus for these regions water stress may be detected only locally. Such countries are for example Albania $\left(10,307 \mathrm{~m}^{3}\right.$ capita $^{-1}$ year $\left.^{-1}\right)$ and Bosnia and Herzegovina $\left(10,693 \mathrm{~m}^{3}\right.$ capita $^{-1}$ year $\left.^{-1}\right)$, as well as Croatia that is the country with the highest TWRW per capita in the Mediterranean region $\left(25,185 \mathrm{~m}^{3}\right.$ capita $^{-1}$ year $\left.^{-1}\right)$.

In the definition for a country on its state of water scarcity or not, it can be noted that the total amount of TRWR for each individual country refers to an averaged value. In fact, the distribution of these water resources is not usually constant in time and space, especially in the case of very large countries, implying that some regions, even if belonging to the same country, may be more affected by the water scarcity issue than the others. In this scenario of water scarcity, the mismanagement of the available water resources might exacerbate the actual situation. Proper management of water resources in the face of changing climate and population growth requires a reliable knowledge of the relationship between their availability and the effective demand. 


\subsection{Water withdrawals and pressure on total renewable water resources}

As in the case of TRWR, water withdrawals in the Mediterranean area are not uniform in space and in time. The difference in water consumption in each country is mostly depending on whether the country is developed or under a developing phase. However, withdrawals of renewable water resources can take place to meet people needs or as consequence of their activities in different sectors. Different indicators have been developed in the last decades in order to investigate on the actual pressure on renewable water resources and thus on the risk of water shortage in the Mediterranean area. Selected indicators are reported here and used to assess the Mediterranean countries in more detail.

\subsubsection{Water Scarcity Indicator}

The Water Scarcity Indicator (WSI) was developed by Falkenmark [37] to compare water availability to primary, or even basic, needs (hygiene and domestic uses), estimating that $50 \mathrm{~L}_{\text {person }}{ }^{-1}$ day $^{-1}$ are needed to satisfy them $[38,39]$. This indicator can be calculated as reported in Eq.1 and identifies the total water resources that are available to the population of a country or region, measuring scarcity as the amount of renewable freshwater that is available for each person each year.

$$
W S I=\frac{P \times W S \times 365}{T R W R} \times 100
$$

where:

- $\quad P=$ population of a country (millions of inhabitants).

- $\quad$ WS = water supply $\left(50 \mathrm{~L}_{\text {person }}{ }^{-1}\right.$ day $\left.^{-1}\right)$.

- $\quad$ TRWR $=$ total renewable water resources of a country $\left(m^{3}\right.$ year $\left.{ }^{-1}\right)$.

Outcomes from calculations related to WSI have been summarized in Table 1. The higher WSI have been detected for the southern countries of the Mediterranean basin (namely Algeria, Cyprus, Egypt, Israel, Lebanon, Libya, Malta, Morocco, State of Palestine and Syrian Arab Republic), for which the WSI ranged from 2.1 to $17.5 \%$, denoting that these countries are experiencing chronic or absolute water scarcity. On the contrary, the lowest WSI values $(\leq 0.3 \%)$ for countries allocated in the North-West part of the Mediterranean basin indicate abundant water resources nationally or occasional and local water stress. Intermediate values of WSI such as for France (0.6\%), Italy (0.6\%), Spain (0.8\%), and Turkey $(0.7 \%)$ suggest that these countries are already experiencing water stress, but not at the last stage of absolute water scarcity. Furthermore, as it can be observed from Table 1, outcomes from WSI calculations were in accordance with data provided by FAO on water scarcity distribution (Fig. 4) [36].

\subsubsection{Water Exploitation Index and Millennium Development Goal (MDG) Indicator 7.5.}

As mentioned in the previous Section 3.2.1., WSI refers only to the part of freshwaters that are used to meet people primary needs. The European Environmental Agency (EEA) has then defined an indicator, commonly known as Water Exploitation Index (WEI), which instead considers the total freshwater 
withdrawn each year, expressed in percentage of the TRWR. This parameter is an indication of the pressure on the renewable water resources. According to EEA, countries with a WEI lower than $20 \%$ are generally identified as non-stressed. On the contrary, if the threshold value of $20 \%$ is exceeded, the country may be considered as water stressed. Furthermore, for WEI indicators higher than $40 \%$, severe water stress may occur, indicating that the actual water use is unsustainable. In the past, WEI values could be found on the AQUASTAT database [36], which today report this kind of information as an indicator called Millennium Development Goal (MDG) Indicator 7.5.. Both the indicators are defined as the percentage of freshwater withdrawn to TRWR, therefore WEI and MDG are the same, except for their name. It was possible to refer to MDG 7.5. as soon as the Millennium Declaration was introduced, in which The Millennium Development Goals and targets have been defined [40]. Therefore, in this section only considerations on the MDG 7.5. will be provided. As summarized in Table 1, only a few Mediterranean countries, namely Albania (3.9\%), Bosnia and Herzegovina (1.1\%), Croatia (0.6\%), France (12.5\%), Greece (16.4 \%), Italy (17.9\%) and Slovenia (2.9\%), have a MDG 7.5. lower than 20\%. In contrast, most of the countries exceed the threshold value of $40 \%$, or even $100 \%$ (e.g. Libya; Table 1), highlighting that these countries are experiencing a chronic water scarcity period and therefore are managing their TRWR in a non-sustainable way.

\subsubsection{Sustainable Development Goal (SDG) 6.4.2 Water Stress Indicator.}

Recently, 17 Sustainable Development Goals (SDGs) were proposed by UN Member States within the 2030 Agenda for Sustainable Development framework, and the SDG 6 focuses on clean water and sanitation. Among the other proposed indicators, the SDG 6.4.2. Water Stress indicator [41] (Table 1) will provide an indication of the water stress level on TRWR due to the pressure of human and economic activities, considering also environmental water requirements. In particular, SDG 6.4.2. WS has been then derived from the MDG 7.5. with the introduction of environmental flow requirements, which denote the quantity and timing of freshwater flows required to sustain freshwater ecosystems and the human livelihoods and well-being that depend on them. As reported in Table 1, the SDG 6.4.2. WS is in the range of $25-100 \%$ for eight of the countries that have been considered (Cyprus, Italy, Lebanon, Malta, Morocco, Spain, State of Palestine and Turkey), meaning that they are facing serious water stress, at least during parts of the year. It can be also observed that a similar number of countries is below that threshold, perhaps due to a more sustainable use of water or simple because of their high TWRW value. However, there are many countries with an SDG 6.4.2. WS higher than 100\% (e.g. Libya, Algeria, Syria), resulting in an overuse of their available total renewable freshwater resources. These values indicate that water stress not only is hindering the sustainability of freshwater resources, but it might also hamper the social and economic development, negatively affecting the population. Comparing the three indicators together (i.e. WSI, MDG 7.5. and SDG 6.4.2. WS), it can be noted that 
for each of the Mediterranean countries WSI < MDG 7.5. $\leq$ SDG 6.4.2. That trend and discrepancy among values for the same country highlight different methodology that was applied for the calculation of these parameters. Although all three parameters consider the same amount of TRWR, WSI values are the lowest since basic people needs only represent a small part of total freshwaters resources, whereas MDG 7.5. and SDG 6.4.2 consider also non-basic and environmental requirements and therefore give much higher values.

\subsubsection{Dependency Ratio}

Fig. 5 shows a map which reports the percentage of TRWR originating outside the country [36]. In Fig. 5 , the contribution of transboundary water to the TRWR is expressed as percentage, which is commonly known as Dependency Ratio (DR). DR may theoretically vary in the range from 0 to $100 \%$. A country in which the DR equals $0 \%$ denotes a situation in which all of the country's water resources are generated within its territory (e.g. an island country), while a DR of $100 \%$ indicates that a country receives all the renewable water resources from the other countries. Most of the Mediterranean countries have a DR lower than $25 \%$, indicating that only a small percentage of its TRWR is coming from the neighbouring countries (e.g. rivers or groundwater basins shared by more countries). DR, estimating the part of water resources that a country can effectively control, can also be viewed as an indicator of a potential or current conflict between countries for water resources, especially for the ones that already have a low TRWR. For example, it is interesting to compare Croatia and Israel, the two countries that have a similar DR (64 vs 58\%, respectively) but very different TRWR (25,185 vs $214 \mathrm{~m}^{3}$ capita $^{-1}$ year ${ }^{-1}$, respectively). While both receive more than a half of their TRWR from the neighbouring countries, Croatia would have enough water resources even without that part. Israel, on the other hand, has a low TRWR, and therefore every further decrease is important to consider. Even more extreme is the example of Egypt that almost completely (DR > 98\%) relies on the neighbouring countries for its renewable water supply.

\subsection{Water withdrawals for agricultural purposes}

Among others, total water withdrawals (TWW) [36] are intended for industrial, municipal, and agricultural purposes. As it can be observed from Table 1, many countries bordering the Mediterranean Sea, due to ever increasing water withdrawals, are increasing the use of their TRWR. In some cases, namely Egypt, Israel, Libya, and Tunisia, TWW is currently exceeding TRWR, most probably due to the use of non-renewable water resources, confirming the water scarcity situation that they are currently experiencing. The agricultural sector is the main water user worldwide, accounting for $70 \%$ of total renewable withdrawals on average [42]. Due to the population growth, it was also estimated that the percentage may rise up to $95 \%$ in some developing countries [11]. In the last decades, agriculture has considerably contributed to the occurrence of water overuses, the situation when recharge rates of renewable water resources are exceeded by withdrawals, eventually leading to water scarcity. Focusing 
on the Mediterranean basin, the situation is not different. As reported in Table 1, agriculture contributes with a high withdrawal percentage, that is mostly in the range between 50 and $90 \%$ (percentage of Agriculture Water Withdrawal (AWW) [36] to TWW). The highest percentages of AWW have exceeded the $80 \%$ for countries such as Greece (80.0\%), Libya (83.2\%), Morocco (87.8\%), Syrian Arab Republic (87.5\%), and Turkey (85.1\%), which are at the same time mostly the countries with scarce water resources, low TRWR and high water stress.

\section{Use of RW in the Mediterranean area}

This section will assess the possibility of employing RW as novel strategy to cope with the increasing water demand, with particular reference to agriculture needs.

\subsection{Barriers and potential associated with the use of RW}

Most of wastewater is re-introduced into the hydrological cycle without being neither collected nor treated [43], representing de facto a source of pollution of the uncontaminated water resources, namely groundwater and surface water. These polluted waters could then be used as an irrigation source in the field of agriculture, eventually leading to issues such as deterioration in soil structure (i.e. soil clogging and thus alteration of infiltration due to high content of suspended solids in the water), soil salinization and phytotoxicity. However, if all wastewater was properly treated, it could be used in various sectors, including agriculture, as a "non-conventional" source, helping to cope with the issues of water scarcity and use of water with poor quality. The use of RW for agricultural purposes is commonly perceived as riskier than using surface water resources, representing a serious obstacle to accepting a potential novel approach of using them, even though it could preserve the available freshwaters and safeguard the public and environmental health. The most common concerns related to the perceived risks to human health and to the possible consumption of food that has been irrigated by using RW are associated with the potential exposure to pathogens (i.e. viruses, bacteria, helminths and protozoa), toxic, persistent and emerging contaminants (i.e. microplastics, hydrocarbons, pesticides, etc.). These concerns are further fuelled by the absence of a univocal regulation for the use of RW in agriculture. Nonetheless, RW is already being used for irrigational (mostly for green and recreational areas and lesser for crops), municipal (i.e. street washing and technical water) and industrial purposes (i.e. firefighting, process and cooling water). For this reason, in the last decades there has been a growing interest by different institutes worldwide on the definition of a regulatory framework, which would allow the use of RW for the irrigation of edible agricultural products without putting human health to risk. The first attempt was made by the State of California, which provided the criteria on the use of RW in 1978 [44]. Then, different water reuse guidelines have been developed by international organisations such as World Health Organization (WHO) [18], United Nations Environment Programme (UNEP) $[19,20]$, United Nations Water Decade Programme on Capacity Development 
(UNW-DPC) [21], International Organization for Standardization (ISO) [22] and Food and Agriculture Organization (FAO) [23], respectively. However, work is still underway to move from guidelines to a more structured regulatory framework. At European level, for instance, the use of RW was identified as a good practice and encouraged by two existing EU directives $[45,46]$ that, on the other hand, did not provide any conditions or requirements for the safe use of RW. Nevertheless, EU has currently proposed a legislative plan on minimum requirements for the use of RW for irrigation and groundwater recharge [24]. Therefore, despite the fact that use of RW is progressively taking place in the Mediterranean area (i.e. Cyprus, Egypt, Israel, Libya, Spain, Syrian Arab Republic, Tunisia, etc.), mostly for aquifer recharge and irrigation in agriculture, this practice is limited by the existence of different principles, regulations and applications in each Mediterranean country. Israel and Italy may be compared as two extreme examples: despite being the leader in the use of RW in the Mediterranean basin, Israeli legislation consider only around 10 parameters; on the contrary, in Italy about fifty restrictions must be respected, and only a small proportion of its treated wastewater is reused [47]. Table 3 provides a comparative review of guidelines and regulations governing Mediterranean countries, all of them being different. Hence, the necessity to define a new legislation, which should eliminate differences as well as prescribe measures for risk management $[48,49]$ in order to the protect public health and the environment.

An additional limiting factor for studying the potential associated with the use of RW is the lack of data on the total amount of wastewater that is generated, collected, and safely treated. In order to cope with this issue, the Goal 6 on Water and Sanitation of SDG agenda 2030 [50] will provide countries of the United Nations Member States with the definition of flexible methods to collect the necessary data, which will be monitored in line with the existing capacity and resources of the countries and will be used to fill the current data gaps.

The use of RW may allow the conservation and better allocation of TRWR, particularly in areas under water stress, resulting in an increase in the total available water supply and providing a solution to water scarcity issues. Consequently, the lower energy required by the wastewater treatment and management if compared with the one currently requested by operations such as pumping groundwater, importing water, desalinating seawater or exporting wastewater, may represent a climate change mitigation measure through the reduction of greenhouse gases [51]. The use of RW may also reduce the total amount of discharges and, thus, the level of nutrients or other contaminants entering waterways and sensitive riverine or marine environments, resulting in a decrease in the phenomenon of eutrophication and its main related problems. Moreover, the high nutrient content, by which domestic and municipal wastewater are commonly characterized, could be exploited as valuable 
source for growing crops, and resulting in a reduction of the supply of chemical fertilizers in the agriculture field [52].

However, in order to use RW in agriculture, produced municipal wastewater needs to be previously treated to appropriate level to meet specific water quality requirements. It has indeed been observed that if domestic and urban wastewater are released to the environment without a proper level of treatment, they may cause several water-related diseases, including schistosomiasis and cholera [10]. Therefore, in order to increase and improve the level of treatment, different BATs have been currently applied, considering existing and new efficient treatment methods [25]. With this purpose, particular attention is paid to the water disinfection process and thus to the removal of pathogens through the implementation of advanced multi-barrier treatment schemes, which can include the application of different methods such as micro- or ultra-filtration [53], reverse osmosis [53], and Advanced Oxidation Processes (AOPs - with chemicals: hydrogen peroxide, chlorine, ozone and hypochlorite [54] or by means of physical devices: UV light [55] or other mechanical techniques [56]). Moreover, different nature-based solutions can be used for water reclamation. For example, constructed wetlands are the systems that mimic processes occurring in natural wetlands in order to treat wastewater. They have a low environmental impact, low operation costs and can also provide ecosystem services, which makes them especially suitable for small communities of decentralised treatment [52]. As advantage, the use of RW may therefore lead to an improvement of the current treatment efficiencies in wastewater treatment plants (WWTPs), preventing thus the discharge of treated poor-quality wastewater into receiving water bodies. However, higher efficiencies could be associated with higher treatment costs. Moreover, transportation costs should be considered as well since the location of WWTPs is not always in the vicinity of the RW use sites.

\subsection{Potential of RW use in agriculture for the Mediterranean region}

In order to evaluate the impact of agriculture on the availability of TRWR, it is necessary to consider the crops water needs. The AQUASTAT database reports a parameter known as Irrigation Water Requirement (IWR), which represents the total amount of water exclusive of precipitation and soil moisture that is required for normal crop production. Values of IWR for each of the Mediterranean countries are summarized in Table 2. Crops water needs are commonly satisfied by exploiting freshwater resources, limiting their availability. The AQUASTAT database of FAO has estimated that about $44 \%$ of global freshwater withdrawals occur for agricultural purposes, whereas the remaining $56 \%$ is intended for direct consumption and later is released into the environment as wastewater. However, at least a part of this large amount of wastewater, if properly treated, may be exploited as "non-conventional" source to reduce the pressure on TRWR. Unfortunately, data on generation, treatment and use of wastewater are in most of the cases too old or even missing. An example of the 
lack of this important information is provided by the ACQUASTAT database, which however is the main information system of water and agriculture worldwide. To fill this gap, the UN-Water Integrated Monitoring Initiative for the SDG 6 (Clean Water and Sanitation) within the framework of the 2030 Agenda for Sustainable Development will support countries, including those belonging to the Mediterranean area, in collecting data through the compilation of periodic data report on generated, collected and safely treated wastewater, respectively [50]. Even though the final data are not available yet, in this study it was possible to perform an analysis on the potential use of RW by exploiting preliminary estimated data that have been provided at the beginning of the same initiative. The analysis started considering the safely treated wastewater (STWW) (Table 2), for which the estimation tracks the percentage of wastewater flows from households, services and industrial premises that are treated in compliance with national or local standards. It is by no means certain that the total amount of safely treated wastewater can be directly used for irrigation purposes due to various reasons (e.g. nonexistence of the regulatory framework; different chemical, physical and biological characteristics of effluents from WWTPs depending on methods that have been used for their treatment; irrigation areas being too far from the WWTPs). However, considering the data on STWW (Table 2) and assuming that the total amount of WWTPs effluents was treated according to standards in order to allow their safe use in agriculture, it was possible to state that STWW could alone meet an average of $19.1 \%$ (percentage of STWW to IWR) of the total irrigation water requirement. The average was calculated considering all the Mediterranean countries, except for those with a STWW/IWR percentage higher than 100\% (namely France, Malta, and Slovenia). Following the same logic of reasoning as for the STWW, if it were then assumed that the collected wastewater (CWW) (Table 2) or even the generated wastewater (GWW) (Table 2) could also be adequately treated in order to be used in agriculture, IWR of the Mediterranean region would be satisfied at $32,1 \%$ and $35,6 \%$, respectively. Therefore, the use of RW would certainly represent a significant contribution to meet water needs, reducing the current pressure on TRWR. However, in Table 2 are listed the individual percentages of the three parameters (STWW, CWW, and GWW) for each Mediterranean country.

Further considerations on the potential RW use could be provided by taking into account the cultivated areas (CA) in the Mediterranean basin (Table 2), which, according to the AQUASTAT database, are defined as the sum of arable lands and areas under permanent crops [36]. In order to cope with increasing food demand, these areas have progressively grown over the last fifty years, mostly at the expense of forest, wetland, and grassland habitats [57]. However, the cultivated areas can be further categorized as i) area equipped for full control irrigation: total (AET) and ii) area equipped for full control irrigation: actually irrigated (AEAI), (Table 2). As mentioned before, some of the Mediterranean countries, have percentages of STWW/IWR higher than 100\%, since their STWW were higher than the 
corresponding IWR (Table 2). This means that these countries not only could fully meet the irrigation water requirement by using their STWW, but also have a possibility to use a residual RW volume for different purposes. This surplus in RW could be calculated as difference between STWW and IWR, and therefore it would be equal to $4.94610^{9} \mathrm{~m}^{3}$ year ${ }^{-1}$ for France, $0.00610^{9} \mathrm{~m}^{3}$ year-1 for Malta, and 0.042 $10^{9} \mathrm{~m}^{3}$ year ${ }^{-1}$ for Slovenia, respectively. Then, considering for instance the French country, this further quantity of $4.94610^{9} \mathrm{~m}^{3}$ year-1 would lead to an extension of the irrigable area, which could rich 4,273.9 $10^{3} \mathrm{ha}$. This potentially irrigable area would be higher than the AET $\left(2,69110^{3} \mathrm{ha}\right)$, but lower than CA $\left(19,34810^{3} \mathrm{ha}\right)$, indicating that in the case of the French country, the use of SSTW would make it possible to meet the irrigation needs of the actually irrigated area as well as of the total equipped area for irrigation, and also of part of the cultivated area that is not equipped for irrigation. The same could be said for Malta, for which IWR is $0.01210^{9} \mathrm{~m}^{3}$ year-1 and AEAI is $310^{3} \mathrm{ha}$. Then, the potentially irrigable area would be $4.510^{3}$ ha, which would be higher than the AET ( $\left.410^{3} \mathrm{ha}\right)$ and lower than CA ( $\left.1110^{3} \mathrm{ha}\right)$. Also the same for Slovenia, which has an IWR of $0.00110^{9} \mathrm{~m}^{3}$ year-1 and an AEAI of $310^{3}$ ha, with a potentially irrigable area of $12910^{3}$ ha that would be higher than the AET ( $310^{3}$ ha) and lower than CA (238 $10^{3}$ ha). However, contrary to France and Malta, for Slovenia it can be noted that CWW and GWW are not the same as STWW. Hence, if CWW would be considered instead of STWW for the calculation of the potentially irrigable area, it would increase from $12910^{3}$ ha to $22810^{3}$ ha, which would be lower than the AET ( $310^{3} \mathrm{ha}$ ) and still be lower than CA (238 $\left.10^{3} \mathrm{ha}\right)$. However, if GWW would be used for the calculation of the potentially irrigable area, it would further increase to $26710^{3}$ ha and this time would be higher than $23810^{3}$ ha, indicating that it could be not only possible to satisfy the irrigation needs of both the actually irrigated area and the total equipped area for irrigation, but the cultivated area would be even extended. Hence, the importance of treating all the generated wastewater (GWW) in order to increase the potential of the RW use, resulting in a potential increase in arable land in use and consequently in agricultural production.

Considering the use of STWW, CWW or GWW to cover at least a part of IWR, gains much more on importance when water scarce countries are considered. Since Israel collects all of its GWW, and more than $90 \%$ of it is safely treated, it can be used to cover more than $50 \%$ of its IWR and thus reduce the pressure on renewable water resources. However, Israel already reuses a large portion of its wastewater for agriculture [47]. Algeria could also cover more than 50\% of its IWR in the case of CWW or GWW reuse, while that percentage falls considerably for STWW since most of its CWW or GWW is not safely treated. Table 2 gives also other notable examples (e.g. Cyprus, Greece or Lebanon), leading to the conclusion that treated wastewater should be given the importance that it deserves as a resource that can help to mitigate effects of water scarcity. 


\section{Current research on the use of non-conventional water resources in the Mediterranean region}

Partnership for Research and Innovation in the Mediterranean Area (PRIMA) is a joint programme that focuses on the achievement of integrated and sustainable management of agro-food and water systems in the Mediterranean region (PRIMA, 2020). Thus, PRIMA will also contribute to United Nations' Agenda 2030 through the achievement of the Sustainable Development Goals (SDGs). PRIMA aims to build research and innovation capacities and to develop knowledge and common innovative solutions for agro-food systems, to make them sustainable and more climate resilient, taking into account also environmental, social and other factors. The Partnership consists of 19 countries in total, including some European Union Member States, Horizon 2020 Associated Countries and Mediterranean Partner Countries. Although still in its beginnings, PRIMA has already financed projects that deal with overcoming water scarcity in the Mediterranean agricultural sector. For example, the main objective of the project Safe and sustainable solutions for the integrated use of non-conventional water resources in the Mediterranean agricultural sector (FIT4REUSE) is to provide safe, locally sustainable and accepted ways of water supply for the Mediterranean agricultural sector by exploiting non-conventional water resources, namely treated wastewater and desalted water. In particular, FIT4REUSE will focus on innovative treatment technologies and on the use of non-conventional water resources in agriculture and for aquifer recharge, including the partners from 7 Mediterranean countries (Spain, France, Italy, Greece, Turkey, Israel and Tunisia). The project organises its activities within the three main pillars: i) innovation of wastewater treatment and desalination technologies, ii) application of non-conventional water resources for irrigation, fertigation and aquifer recharge, as direct and indirect water reuse schemes, and iii) assessment and regulation of the solutions and schemes proposed, followed with the engagement of research, governmental and industrial partners from different parts of the Mediterranean region.

\section{Conclusions}

Climate change is expected to have a growing impact on water resources worldwide, especially for the Mediterranean area, which is already experiencing issues related to water scarcity. Higher air temperatures could lead to increased evapotranspiration rates, radically modifying the soil characteristics and compromising the natural recharge of groundwater resources. The growing population and the global trend of urbanization will require higher volumes of available water and ensuring enough supplies in terms of both quantity and quality is a primary concern, since it might be seriously hindered by the temporal and spatial variability of water resources and climate change. Agriculture is one of the main sources of pollution of renewable water resources due to the widespread use of nutrients, pesticides, and other common contaminants. Within this context, there is an 
increasing interest in improving the agricultural productivity on a sustainable basis, while keeping unaltered natural renewable water resources and minimizing the negative impact that agriculture may have on the environment. Agriculture is not only a cause of contamination for renewable water resources, but it is also the reason of their increased consumption. The use of non-conventional water resources, and in particular the use of RW could be an effective solution to the issue of water scarcity. In addition to being a valuable water source for the mitigation of the impacts of climate change, RW could also lead to a radical change in the irrigation practice, promoting circular economy and use of nutrients present in wastewater in order to reduce artificial fertilizers consumption. However, the definition of a new regulatory framework might be necessary to specify water quality control and monitoring criteria for the safe use of RW, and thus, overcome the limitations of current legislation. For the Mediterranean area it has been observed that the use of RW could significantly contribute to meet water needs and, therefore, to decrease the current pressure on TRWR, providing a novel strategy to face water scarcity and climate change issues. Furthermore, for some of the Mediterranean countries, the use of RW could increase the extension of cultivated areas under irrigation, favouring a higher food production. However, further studies and monitoring activities for data collection will be needed on both local and national scales in order to accurately quantify the exact amount of RW that could be used in the agriculture sector, with the main aim of dealing with the deficit of available freshwaters, which are currently characterized by lower availability of renewable waters and higher withdrawals. 


\section{Acknowledgements}

This work was supported by the FIT4REUSE Project ("SaFe and sustalnable soluTions FOR the integRatEd USE of non-conventional water resources in the Mediterranean agricultural sector" - Partnership for Research and Innovation in the Mediterranean Area - PRIMA - Grant Agreement n. 1823 https://fit4reuse.org/), and the VALUE CE-IN Project ("Valorizzazione di acque reflue e fanghi in ottica di economia circolare e simbiosi industriale" - POR-FESR Emilia Romagna Region 2014-2020 https://valuecein.eu/). 


\section{References}

[1] T. Bucak, D. Trolle, H.E. Andersen, H. Thodsen, Ş. Erdoğan, E.E. Levi, N. Filiz, E. Jeppesen, M. Beklioğlu, T. Bucak, Future water availability in the largest freshwater Mediterranean lake is at great risk as evidenced from simulations with the SWAT model, Sci. Total Environ. 581-582 (2017) 413-425.

[2] P. Segurado, C. Almeida, R. Neves, M.T. Ferreira, P. Branco, Understanding multiple stressors in a Mediterranean basin: Combined effects of land use, water scarcity and nutrient enrichment, Sci. Total Environ. 624 (2018) 1221-1233.

[3] A.S. Sánchez, V.J. Subiela, Analysis of the water, energy, environmental and socioeconomic reality in selected Mediterranean countries (Cyprus, Turkey, Egypt, Jordan and Morocco), Desalination. 203 (2007) 62-74.

[4] H. Ling, H. Xu, J. Fu, Temporal and Spatial Variation in Regional Climate and its Impact on Runoff in Xinjiang, China, Water Resour. Manag. 27 (2013) 381-399.

[5] S. Mukherjee, C. Debashis, Urbanization and Demand for Water and Sanitation Services: An Analysis on Cross-Region Investment Requirements, Natl. Inst. Public Financ. Policy (NIPFP), New Delhi, Indian Inst. Foreign Trade (IIFT), New Delhi. (2016) 1-23.

[6] E. Fukase, W. Martin, Economic growth, convergence, and world food demand and supply, World Dev. 132 (2020) 104954.

[7] J. Liu, Q. Liu, H. Yang, Assessing water scarcity by simultaneously considering environmental flow requirements, water quantity, and water quality, Ecol. Indic. 60 (2016) 434-441.

[8] Q. Li, W. Wang, X. Jiang, D. Lu, Y. Zhang, J. Li, Optimizing the reuse of reclaimed water in arid urban regions: A case study in Urumqi, Northwest China, Sustain. Cities Soc. 51 (2019) 101702.

[9] EC (2007). Communication from the Commission to the Council and the European Parliament, Addressing the challenge of water scarcity and droughts in the European Union. Brussels, 18.07.07, COM(2007)414 final., (2007).

[10] WWAP, 2017. United Nation World Water Assessment Programme. The United Nations World Water Development Report 2017. Wastewater: the Untapped Resource. Unesco, Paris., (2017).

[11] Water at a Glance: the relationship between water, agriculture, food security and poverty. Food and Agriculture Organization of the United Nations, Rome, (2008). 
[12] S. Toze, Reuse of effluent water - Benefits and risks, Agric. Water Manag. 80 (2006) 147-159.

[13] M. Sgroi, F.G.A. Vagliasindi, P. Roccaro, Feasibility, sustainability and circular economy concepts in water reuse, Curr. Opin. Environ. Sci. Heal. 2 (2018) 20-25.

[14] D. Schröter, W. Cramer, R. Leemans, I.C. Prentice, M.B. Araújo, N.W. Arnell, A. Bondeau, H. Bugmann, T.R. Carter, C.A. Gracia, A.C. De La Vega-Leinert, M. Erhard, F. Ewert, M. Glendining, J.I. House, S. Kankaanpää, R.J.T. Klein, S. Lavorel, M. Lindner, M.J. Metzger, J. Meyer, T.D. Mitchell, I. Reginster, M. Rounsevell, S. Sabaté, S. Sitch, B. Smith, J. Smith, P. Smith, M.T. Sykes, K. Thonicke, W. Thuiller, G. Tuck, S. Zaehle, B. Zierl, Ecology: Ecosystem service supply and vulnerability to global change in Europe, Science (80-. ). 310 (2005) 1333-1337.

[15] F. Giorgi, P. Lionello, Climate change projections for the Mediterranean region, Glob. Planet. Change. 63 (2007) 90-104.

[16] S. Somot, F. Sevault, M. Déqué, M. Crépon, 21st century climate change scenario for the Mediterranean using a coupled atmosphere-ocean regional climate model, Glob. Planet. Change. 63 (2008) 112-126.

[17] J. Haarhoff, B. Van der Merwe, Twenty-five years of wastewater reclamation in Windhoek, Namibia, Water Sci. Technol. 33 (1996) 25-35.

[18] Guidelines for the safe use of wastewater, excreta and greywater, World Health Organization (WHO), (2006).

[19] Guidelines for municipal wastewater reuse in the Mediterranean region, United Nations Environment Programme (UNEP), (2005).

[20] Development of performance indicators for the operation and maintenance of wastewater treatment plants and wastewater reuse, United Nations Environment Programme (UNEP), (2011).

[21] Proceedings on the UN-Water project "Safe use of wastewater in agriculture", United Nations Water Decade Programme on Capacity Development (UNW-DCP), (2013).

[22] ISO/TC282 Water reuse (under devlopment), International Organization for Standardization (ISO), (n.d.).

[23] Water quality for agriculture, Food and Agriculture Organization (FAO), (1994).

[24] Position of the Council on the adoption of a Regulation of the European Parliament and of the Council on minimum requirements for water reuse, Brussels, 15 April 2020, (2020). 
[25] L. Rizzo, W. Gernjak, P. Krzeminski, S. Malato, C.S. McArdell, J.A.S. Perez, H. Schaar, D. FattaKassinos, Best available technologies and treatment trains to address current challenges in urban wastewater reuse for irrigation of crops in EU countries, Sci. Total Environ. 710 (2020) 136312.

[26] D. Hendricks, Fundamentals of water treatment unit processes: physical, chemical, and biological, IWA Publishing, ISBN 978-1-4200-6191-8, 2011.

[27] L. Metcalf, H.P. Eddy, G. Tchobanoglous, Wastewater engineering: treatment, disposal, and reuse, 4th ed., Mcgraw-Hill, 2002.

[28] United Nations. Department of Economic and Social Affairs Population Dynamics. World Urbanization Prospects, (2018).

[29] L. Boithias, V. Acuña, L. Vergoñós, G. Ziv, R. Marcé, S. Sabater, Assessment of the water supply: Demand ratios in a Mediterranean basin under different global change scenarios and mitigation alternatives, Sci. Total Environ. 470-471 (2014) 567-577.

[30] National Centers for Environmental Information, (2020).

[31] P.R. Hunter, Climate change and waterborne and vector-borne disease, J. Appl. Microbiol. 94 (2003) 37-46.

[32] S.K. Moore, V.L. Trainer, N.J. Mantua, M.S. Parker, E.A. Laws, L.C. Backer, L.E. Fleming, Impacts of climate variability and future climate change on harmful algal blooms and human health, Environ. Heal. 7 (2008) 1-12.

[33] Z. Rengel, Soil pH, Soil Health and Climate Change, in: Soil PH, Soil Heal. Clim. Chang. Soil Biol. Vol 29, 2011: pp. 69-85.

[34] M.T. Kahil, A. Dinar, J. Albiac, Modeling water scarcity and droughts for policy adaptation to climate change in arid and semiarid regions, J. Hydrol. 522 (2015) 95-109.

[35] S. Whateley, S. Steinschneider, C. Brown, A climate change range-based method for estimating robustness for water resources supply, Water Resour. Res. 50 (2014) 8944-8961.

[36] AQUASTAT website. Food and Agriculture Organization of the United Nations (FAO), [website accessed on February 14th, 2020], (2019).

[37] M. Falkenmark, J. Lundqvist, C. Widstrand, Macro-scale water scarcity requires micro-scale approaches, Nat. Resour. Forum. 13 (1989) 258-267. 
[38] B. Reed, B. Reed, Technical notes on drinking-water, sanitation and hygiene in emergencies, World Health Organization: Water, Engineering and Development Centre, Loughborough University, (2013) 1-4.

[39] F. Molle, P. Mollinga, Water poverty indicators: conceptual problems and policy issues, Water Policy. 5 (2003) 529-544.

[40] United Nations, 2005. World Summit on The Millennium Development Goals (MDGs), (2005).

[41] United Nations, 2018. Clean Water and Sanitation in the 2030 Agenda for Sustainable Development. Progress on Level of Water Stress - Global baseline for SDG indicator 6.4.2, (2018).

[42] FAO, The state of the world's land and water resources for food and agriculture (SOLAW): managing systems at risk. Food and Agriculture Organization of the United Nations, Rome and Earthscan, London, (2011).

[43] O.B. Akpor, Wastewater effluent discharge: Effects and treatment processes, in: Int. Conf. Chem. Biol. Environ. Eng., 2011.

[44] State of California, Wastewater reclamation criteria, an excerpt from the California code of regulations, Title 22, Division 4, Environmental Health. Sacramento: Dept. of Health Services, (1978).

[45] Directive 2000/60/EC of the European Parliament and of the Council of 23 October 2000 establishing a framework for Community action in the field of water policy, (2000).

[46] Council Directive 91/271/EEC of 21 May 1991 on Urban Waste Water Treatment, (1991).

[47] S. Lavrnić, M. Zapater-Pereyra, M.L. Mancini, Water Scarcity and Wastewater Reuse Standards in Southern Europe: Focus on Agriculture, Water. Air. Soil Pollut. 228 (2017) 251 (1-12).

[48] ISO 20426/2018 Guidelines for health risk assessment and management for non-potable water reuse, International Organization for Standardization (ISO), (2018).

[49] ISO 16075/2015 Guidelines for treated waste water use for irrigation projects, International Organization for Standardization (ISO), (2015).

[50] United Nations, 2018. Clean Water and Sanitation in the 2030 Agenda for Sustainable Development. Progress on Wastewater Treatment - Piloting the monitoring methodology and initial findings for SDG indicator 6.3.1, (2018). 
[51] S. Eslamian, Urban water reuse handbook, CRC Press - Taylor \& Francis Group, 2016.

[52] S. Lavrnić, M.L. Mancini, Can constructed wetlands treat wastewater for reuse in agriculture? Review of guidelines and examples in South Europe, Water Sci. Technol. 73 (2016) 2616-2626.

[53] C. Cherchi, M. Kesaano, M. Badruzzaman, K. Schwab, J.G. Jacangelo, Municipal reclaimed water for multi-purpose applications in the power sector: A review, J. Environ. Manage. 236 (2019) 561-570.

[54] J.A. Garrido-Cardenas, B. Esteban-García, A. Agüera, Wastewater treatment by Advanced Oxidation Process and their worldwide research trends, Int. J. Environ. Res. Public Health. 17 (2020) 170.

[55] J.C. Espíndola, V.J.P. Vilar, Innovative light-driven chemical/catalytic reactors towards contaminants ofemerging concern mitigation: A review, Chem. Eng. J. 394 (2020).

[56] G. Mancuso, M. Langone, G. Andreottola, A critical review of the current technologies in wastewater treatment plants by using hydrodynamic cavitation process: principles and applications, J. Environ. Heal. Sci. Eng. 18 (2020) 311-333.

[57] FAO, FAO, 2011. The state of the world's land and water resources for food and agriculture (SOLAW) - Managing systems at risk. Food and Agriculture Organization of the United Nations, Rome and Earthscan, London, (2011). 


\section{TABLE CAPTIONS}

Table 1 - Population, water indicators and availability of total renewable water resources in the Mediterranean area.

Table 2 - Analysis on the reuse of RW for the Mediterranean area.

Table 3 - Inventory of legislation on water reuse in the different Mediterranean countries. 


\begin{tabular}{|c|c|c|c|c|c|c|c|c|}
\hline Country & $\begin{array}{l}\text { Population }^{a} \\
\text { (10 inhab.) }\end{array}$ & $\begin{array}{l}\text { WSI } \\
(\%)\end{array}$ & $\begin{array}{c}\text { MDG 7.5. }{ }^{b} \\
\text { (\%) }\end{array}$ & $\begin{array}{c}\text { SDG 6.4.2. WS }{ }^{b} \\
\text { (\%) }\end{array}$ & $\begin{array}{c}\text { TRWR }^{\mathrm{a}} \\
\left(10^{9} \mathrm{~m}^{3} \text { year }^{-1}\right)\end{array}$ & $\begin{array}{c}\text { TWW }^{\mathrm{a}} \\
\left(10^{9} \mathrm{~m}^{3} \text { year }^{-1}\right)\end{array}$ & $\begin{array}{c}\text { AWW } \\
\left(10^{9} \mathrm{~m}^{3} \text { year }^{-1}\right)\end{array}$ & $\begin{array}{c}\text { AWW/TWW } \\
(\%)\end{array}$ \\
\hline Albania & $2.9(2019)$ & $0.2(2017)$ & $3.9(2017)$ & $7.1(2017)$ & $30.2(2017)$ & $1.3(2006)$ & $0.9(2017)$ & 69.6 \\
\hline Algeria & $43.1(2019)$ & $6.8(2017)$ & $84.0(2017)$ & $137.9(2017)$ & $11.7(2017)$ & $10.5(2017)$ & $6.7(2017)$ & 63.8 \\
\hline Bosnia and Herzegovina & $3.3(2019)$ & $0.2(2017)$ & $1.1(2017)$ & $2.7(2017)$ & $37.5(2017)$ & - & - & - \\
\hline Croatia & $4.1(2019)$ & $0.1(2017)$ & $0.6(2017)$ & $1.5(2017)$ & $105.5(2017)$ & $0.7(2017)$ & $0.1(2015)$ & 10.6 \\
\hline Cyprus & $1.2(2019)$ & $2.9(2017)$ & $27.7(2017)$ & $29.5(2017)$ & $0.8(2017)$ & $0.3(2017)$ & $0.2(2017)$ & 59.2 \\
\hline Egypt & $100.4(2019)$ & $3.3(2017)$ & $112.0(2017)$ & $117.3(2017)$ & $57.5(2017)$ & $77.5(2017)$ & $61.4(2017)$ & 79.2 \\
\hline France & $65.1(2019)$ & $0.6(2017)$ & $12.5(2017)$ & $23.1(2016)$ & $211.0(2017)$ & $26.4(2016)$ & $3.1(2016)$ & 11.8 \\
\hline Gibraltar & $<0.1(2019)$ & - & - & - & - & - & - & - \\
\hline Greece & 10.5 (2019) & $0.3(2017)$ & $16.4(2017)$ & $22.7(2016)$ & $68.4(2017)$ & $11.2(2016)$ & $9.0(2016)$ & 80.4 \\
\hline Israel & $8.5(2019)$ & $9.0(2017)$ & $67.3(2017)$ & $103.4(2017)$ & $1.8(2017)$ & $2.3(2017)$ & $1.2(2017)$ & 54.2 \\
\hline Italy & $60.6(2019)$ & $0.6(2017)$ & $17.9(2017)$ & $30.1(2015)$ & $191.3(2017)$ & $34.2(2015)$ & $17.0(2013)$ & 49.7 \\
\hline Lebanon & $6.9(2019)$ & $2.5(2017)$ & $40.2(2017)$ & $58.8(2015)$ & $4.5(2017)$ & $1.8(2015)$ & $0.7(2015)$ & 38.0 \\
\hline Libya & $6.8(2019)$ & $17.5(2017)$ & $822.9(2012)$ & $822.9(2012)$ & $0.7(2017)$ & $5.8(2012)$ & $4.9(2012)$ & 83.2 \\
\hline Malta & $0.4(2019)$ & $16.4(2017)$ & $85.1(2017)$ & $85.1(2017)$ & $0.1(2017)$ & $0.1(2017)$ & $<0.1(2017)$ & 39.8 \\
\hline Monaco & $<0.1(2019)$ & - & - & - & - & - & - & - \\
\hline Montenegro & $0.6(2019)$ & - & - & - & - & - & - & - \\
\hline Morocco & 36.5 (2019) & $2.4(2017)$ & 35.69 (2010) & $49.7(2010)$ & 29.0 (2017) & $10.4(2010)$ & $9.2(2010)$ & 87.8 \\
\hline Slovenia & $2.1(2019)$ & $0.1(2017)$ & $2.9(2017)$ & $6.3(2017)$ & $31.9(2017)$ & $0.9(2017)$ & $<0.1(2017)$ & 0.4 \\
\hline Spain & 46.7 (2019) & $0.8(2017)$ & $28.0(2017)$ & $42.6(2016)$ & $111.5(2017)$ & $31.2(2016)$ & $20.4(2016)$ & 65.2 \\
\hline State of Palestine & $5.0(2019)$ & $11.3(2017)$ & $34.4(2017)$ & $41.1(2017)$ & $0.8(2017)$ & $0.4(2017)$ & $0.2(2017)$ & 43.2 \\
\hline Syrian Arab Republic & $17.1(2019)$ & $2.1(2017)$ & 84.17 (2005) & $125.9(2005)$ & $16.8(2017)$ & $16.8(2005)$ & $14.7(2003)$ & 87.5 \\
\hline Tunisia & 11.7 (2019) & $4.8(2017)$ & $103.3(2017)$ & $121.1(2017)$ & $4.6(2017)$ & $4.9(2017)$ & $3.8(2017)$ & 77.4 \\
\hline Turkey & $83.4(2019)$ & $0.7(2017)$ & $27.8(2017)$ & $43.65(2017)$ & $211.6(2017)$ & $58.8(2017)$ & $50.1(2017)$ & 85.1 \\
\hline
\end{tabular}

a) United Nations data [27]; b) AQUASTAT data [35].

WSI = Water Scarcity Indicator; MDG 7.5. = Millennium Development Goal (MDG) Indicator 7.5.; SDG 6.4.2. WS = SDG 6.4.2. Water Stress indicator.

TRWR = Total Renewable Water Resources; TWW = Total Water Withdrawals; AWW = Agricultural Water Withdrawals.

Table 1 


\begin{tabular}{|c|c|c|c|c|c|c|c|c|c|c|}
\hline Country & $\begin{array}{c}\text { STWW } \\
\left(10^{9} \mathrm{~m}^{3} \text { year }^{-1}\right)\end{array}$ & $\begin{array}{c}\text { STWW/IWR } \\
(\%)\end{array}$ & $\begin{array}{c}\mathrm{CWW}^{\mathrm{a}} \\
\left(10^{9} \mathrm{~m}^{3} \text { year }^{-1}\right)\end{array}$ & $\begin{array}{c}\text { CWW/IWR } \\
\text { (\%) }\end{array}$ & $\begin{array}{c}\text { GWW } \\
\left(10^{9} \mathrm{~m}^{3} \text { year }^{-1}\right)\end{array}$ & $\begin{array}{c}\text { GWW/IWR } \\
\text { (\%) }\end{array}$ & $\begin{array}{c}\text { IWR }{ }^{\mathrm{b}} \\
\left(10^{9} \mathrm{~m}^{3} \text { year }^{-1}\right)\end{array}$ & $\begin{array}{c}\mathrm{CA}^{\mathrm{b}} \\
(1000 \mathrm{ha})\end{array}$ & $\begin{array}{c}\text { AET }^{\mathrm{b}} \\
(1000 \mathrm{ha})\end{array}$ & $\begin{array}{c}\text { AEAI }^{\mathrm{b}} \\
(1000 \mathrm{ha})\end{array}$ \\
\hline Albania & $0.077(2018)$ & 23.9 & $0.115(2018)$ & 35.7 & $0.115(2018)$ & 35.7 & $0.322(2006)$ & $703(2016)$ & $353(2015)$ & $233(2017)$ \\
\hline Algeria & $0.248(2018)$ & 9.9 & $1.439(2018)$ & 57.3 & $1.463(2018)$ & 58.3 & $2.511(2001)$ & $8,417(2016)$ & $1,312(2017)$ & $1,012(2012)$ \\
\hline Bosnia and Herzegovina & $0.001(2018)$ & - & $0.153(2018)$ & - & $0.154(2018)$ & - & - & $1,130(2016)$ & $3(2000)$ & - \\
\hline Croatia & $0.076(2018)$ & - & $0.174(2018)$ & - & $0.181(2018)$ & - & - & $944(2016)$ & $30(2016)$ & $16(2016)$ \\
\hline Cyprus & $0.019(2018)$ & 20.7 & $0.026(2018)$ & 28.3 & $0.051(2018)$ & 55.4 & $0.092(2007)$ & $111(2016)$ & $39(2016)$ & $24(2016)$ \\
\hline Egypt & $1.791(2018)$ & 4.0 & $3.377(2018)$ & 7.5 & $3.891(2018)$ & 8.6 & $45.110(2002)$ & $3,734(2016)$ & $3,823(2016)$ & $3,422(2002)$ \\
\hline France & $7.297(2018)$ & $>100$ & $7.297(2018)$ & $>100$ & $7.297(2018)$ & $>100$ & $2.351(2007)$ & $19,348(2016)$ & $2,691(2016)$ & $1,377(2016)$ \\
\hline Gibraltar & - & - & - & - & - & - & - & - & - & - \\
\hline Greece & $2.244(2018)$ & 41.2 & $2.663(2018)$ & 48.9 & $2.663(2018)$ & 48.9 & $5.441(2007)$ & $3,254(2016)$ & $1,571(2013)$ & $1,165(2013)$ \\
\hline Israel & $0.318(2018)$ & 57.2 & $0.353(2018)$ & 63.5 & $0.353(2018)$ & 63.5 & $0.556(2006)$ & $392(2016)$ & $225(2004)$ & $182(2006)$ \\
\hline Italy & $2.226(2018)$ & 27.7 & $2.483(2018)$ & 31.0 & $2.487(2018)$ & 31.0 & $8.022(2007)$ & $9,054(2016)$ & $4,124(2016)$ & $2,253(2016)$ \\
\hline Lebanon & 0.029 (2018) & 5.5 & $0.204(2018)$ & 38.6 & $0.233(2018)$ & 44.0 & $0.529(2003)$ & $258(2016)$ & $90(2015)$ & 90 (1998) \\
\hline Libya & $0.029(2018)$ & 1.6 & $0.211(2018)$ & 11.5 & $0.241(2018)$ & 13.1 & $1.833(2000)$ & $2,050(2016)$ & $400(2008)$ & $335(2008)$ \\
\hline Malta & $0.018(2018)$ & $>100$ & $0.018(2018)$ & $>100$ & $0.018(2018)$ & $>100$ & $0.012(2007)$ & $11(2016)$ & $4(2013)$ & $3(2016)$ \\
\hline Monaco & - & - & - & - & - & - & - & - & - & - \\
\hline Montenegro & - & - & - & - & - & - & - & - & - & - \\
\hline Morocco & $0.345(2018)$ & 5.9 & $1.064(2018)$ & 18.3 & $1.114(2018)$ & 19.1 & $5.823(2004)$ & $9,592(2016)$ & $1,458(2011)$ & $1,341(2012)$ \\
\hline Slovenia & $0.043(2018)$ & $>100$ & $0.076(2018)$ & $>100$ & $0.089(2018)$ & $>100$ & $0.001(2010)$ & $238(2016)$ & $3(2017)$ & $3(2017)$ \\
\hline Spain & $1.793(2018)$ & 38.3 & $1.989(2018)$ & 42.4 & $1.990(2018)$ & 42.5 & $4.686(2017)$ & $17,033(2016)$ & $3,681(2016)$ & $2,254(2016)$ \\
\hline State of Palestine & - & - & - & - & - & - & $0.093(2003)$ & $147(2016)$ & $120(2016)$ & $24(2003)$ \\
\hline Syrian Arab Republic & - & - & - & - & - & - & $7.123(2000)$ & $5,733(2016)$ & $1,341(2010)$ & $1,210(2000)$ \\
\hline Tunisia & $0.280(2018)$ & 18.0 & $0.358(2018)$ & 23.1 & $0.463(2018)$ & 29.8 & $1.552(2000)$ & $5,232(2016)$ & $460(2012)$ & $380(2011)$ \\
\hline Turkey & $1.195(2018)$ & 4.8 & $2.847(2018)$ & 11.3 & $3.339(2018)$ & 13.3 & $25.140(2004)$ & $23,710(2016)$ & $5,340(2012)$ & 4,997 (2016) \\
\hline
\end{tabular}

a) SDG (6.3.1a) estimated data [51]; b) AQUASTAT data [35].

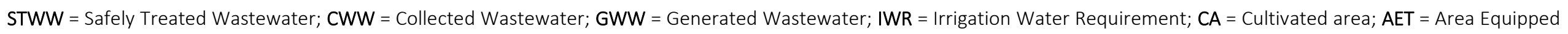
for Full Control Irrigation: Total; AEAI = Area Equipped for Full Control Irrigation: Actually Irrigated.

Table 2 


\begin{tabular}{|c|c|}
\hline Albania & - $\quad$ No specific law for treated wastewater reuse. \\
\hline Algeria & - Algerian law prohibits absolutely the reuse of wastewater for irrigation of crops, it allows though irrigation of crops fodder crops, pasture and trees. \\
\hline $\begin{array}{l}\text { Bosnia and } \\
\text { Herzegovina }\end{array}$ & - No treated wastewater reuse guidelines have been established. \\
\hline Croatia & - $\quad$ No treated wastewater reuse guidelines have been established. \\
\hline Cyprus & - Law N.147/2011 and Ministerial Decree 50/2011. - C Code of Good Agriculture Practice (regulation K.D.P. 407/2002). \\
\hline Egypt & $\begin{array}{l}\text { - Law 48/1992 for the protection of the Nile River and other waterways from pollution. } \\
\text { - } \quad \text { Code for the Reuse of Treated Wastewater in Agriculture issued by The Ministry of Housing, Utilities and New Communities (MHUNC). }\end{array}$ \\
\hline France & $\begin{array}{l}\text { - Decree August } 2 \mathrm{nd}, 2010 \text { for the use of water from treated urban wastewater for crops irrigation and green areas (amended in 2014-JORF N. 0153, July 4th, 2014). } \\
\text { - Health Guidelines for reuse, after treatment, of wastewater for crop and green spaces irrigation (CSHPF, 1991). } \\
\text { - Technical recommendations on wastewater treatments to ensure compliance with the French Guidelines published by the Association of Water Supply and Sewerage } \\
\text { Practitioners (AGHTM, 1996). }\end{array}$ \\
\hline Greece & - $\quad$ CMD 2011: Measures, Limits and Procedures for Reuse of Treated Wastewater; No. 145116; Ministry of Environment, Energy and Climate Change. \\
\hline Israel & - $\quad$ Ministry of Health regulation (2005). \\
\hline Italy & - Decree 11 May 1999, n. 152, Environmental Code. • Decree of Environmental Ministry 185/2003 (DM 185/2003) Technical measures for reuse of wastewater. \\
\hline Lebanon & $\begin{array}{l}\text { - } \quad \text { New Guidelines in Lebanon for wastewater reuse in agriculture are being considered. } \\
\text { - } \quad \text { Lebanese guidelines currently prohibit the reuse of treated wastewater for the growth of crops consumed by humans. }\end{array}$ \\
\hline Libya & - $\quad$ No treated wastewater reuse guidelines have been established. \\
\hline Malta & $\begin{array}{l}\text { - Guidelines on water reuse, including quality standards and a publicly available information system on the quality of the treated effluent are under preparation. } \\
\text { - } \quad \text { Guidelines for irrigation area supplied with treated sewage effluent. Legal Notice LN71/98 forbidding the use of wastewater for the irrigation of any crop for human consumption. }\end{array}$ \\
\hline Morocco & - The National Office of Energy and Drinking Water (ONEE) is responsible for collective sanitation authorising the reuse of RW also at the local level. \\
\hline Slovenia & - $\quad$ No treated wastewater reuse guidelines have been established. \\
\hline Spain & - Royal Decree 1620/2007: The legal framework for the reuse of treated wastewater. \\
\hline $\begin{array}{l}\text { State of } \\
\text { Palestine }\end{array}$ & - No specific law for treated wastewater reuse. \\
\hline $\begin{array}{l}\text { Syrian Arab } \\
\text { Republic }\end{array}$ & - Guidelines in Syria for wastewater reuse in agriculture are being considered. \\
\hline Tunisia & $\begin{array}{l}\text { - Reuse of RW in agriculture regulated by the } 1975 \text { Water Code (law No. 75-16 of } 31 \text { March 1975), the } 1989 \text { Decree No. } 89-1047 \text { (28 July } 1989 \text { ), by the Tunisian standard for the } \\
\text { use of treated wastewater in agriculture (NT 106- } 003 \text { of } 18 \text { May 1989). } \\
\text { - A list of crops that can be irrigated with RW is provided by the Ministry of Agriculture, } 1994 .\end{array}$ \\
\hline Turkey & $\begin{array}{l}\text { - Water reuse was officially legitimised in } 1991 \text { through the regulation for irrigational wastewater reuse issued in by the Ministry of Environment. According to the "Water Pollution } \\
\text { Control Regulations". }\end{array}$ \\
\hline
\end{tabular}




\section{FIGURE CAPTIONS}

Fig. 1 - Global surface land air temperature anomalies ( $\left.{ }^{\circ} \mathrm{C}\right), 1980$ - 2020, [29].

Fig. 2 - Global average annual precipitation $\left(m m\right.$ year $\left.{ }^{-1}\right), 2016$, [29].

Fig. 3 - Mediterranean population growth rate graph, 1950 - 2100, [27].

Fig. 4 - Total renewable water resources per inhabitant $\left(\mathrm{m}^{3}\right.$ capita $^{-1}$ year $\left.^{-1}\right)$ in the Mediterranean area, 2019, [35].

Fig. 5 - Dependency Ratio (DR) - Contribution of transboundary water to the total renewable water resources (\%) in the Mediterranean area, 2019, [35]. 


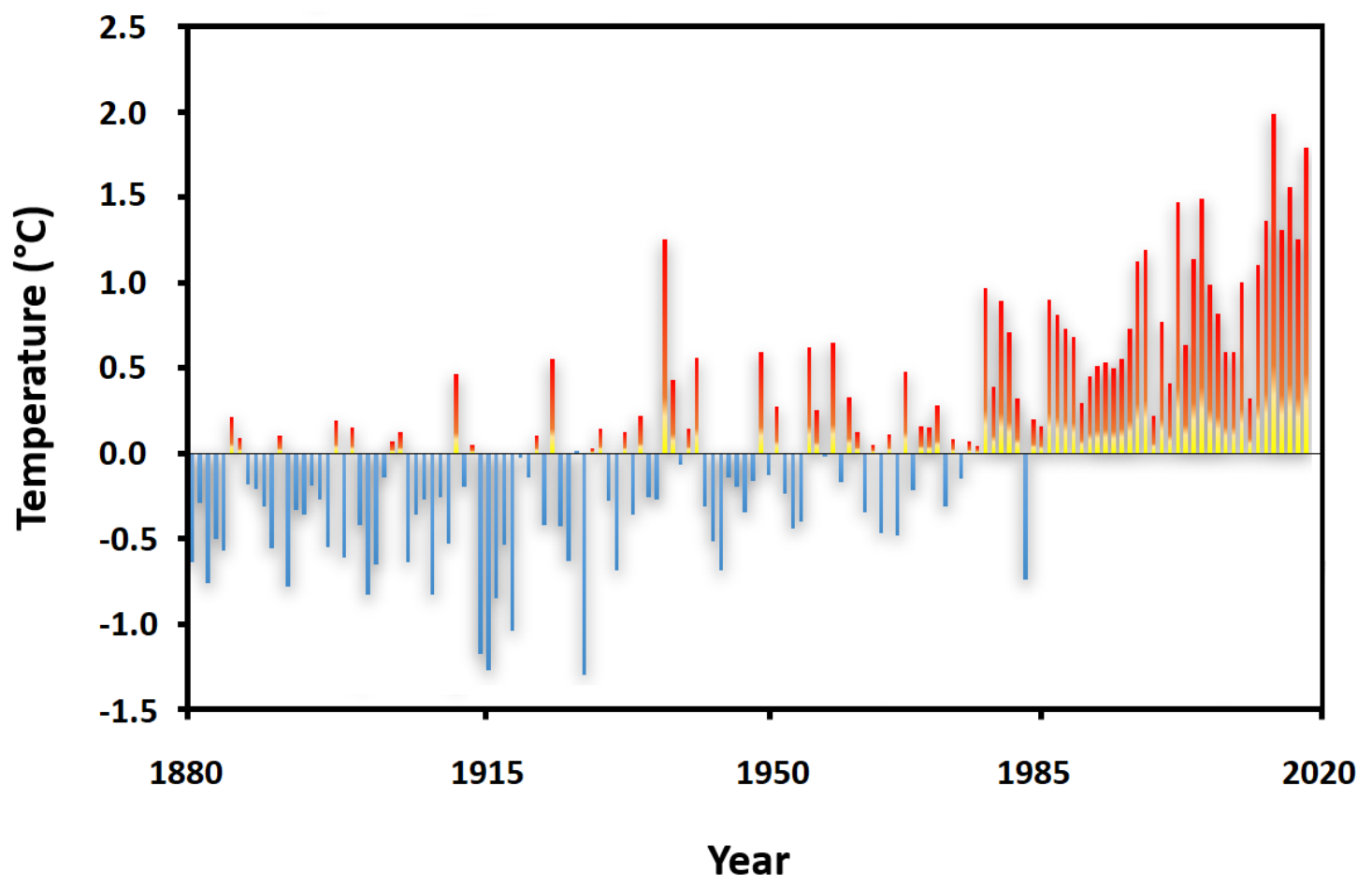

Fig. 1 


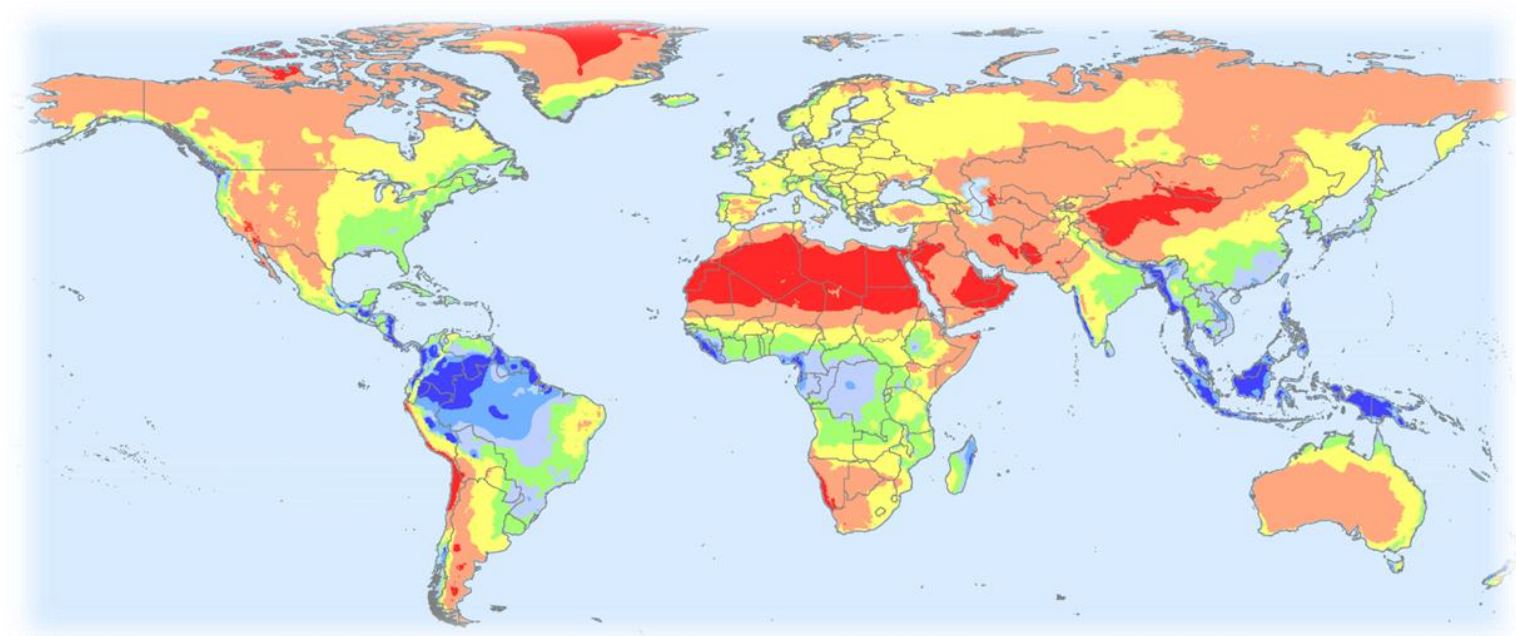

0 - $100 \mathrm{~mm} \mathrm{y}^{-1}$ $1,000-1,500 \mathrm{~mm} \mathrm{y}^{-1}$ $>2,500 \mathrm{~mm} \mathrm{y}^{-1}$
$100-500 \mathrm{~mm} \mathrm{y}^{-1}$

$1,500-2,000 \mathrm{~mm} \mathrm{y}^{-1}$
$500-1,000 \mathrm{~mm} \mathrm{y}^{-1}$

$2,000-2,500 \mathrm{~mm} \mathrm{y}^{-1}$

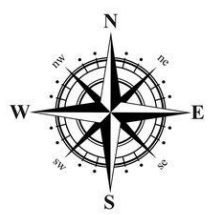

Fig. 2 


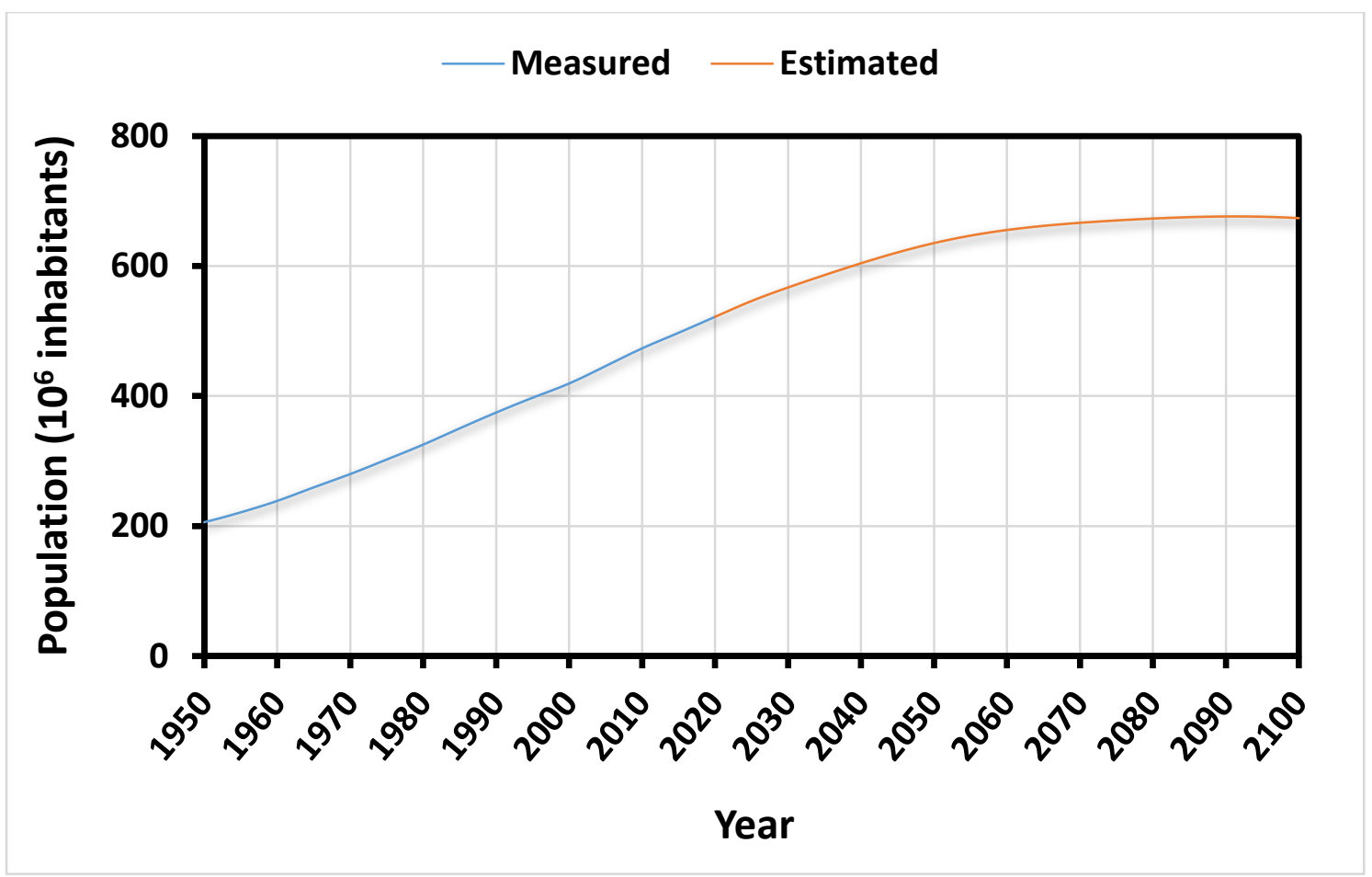

Fig. 3 


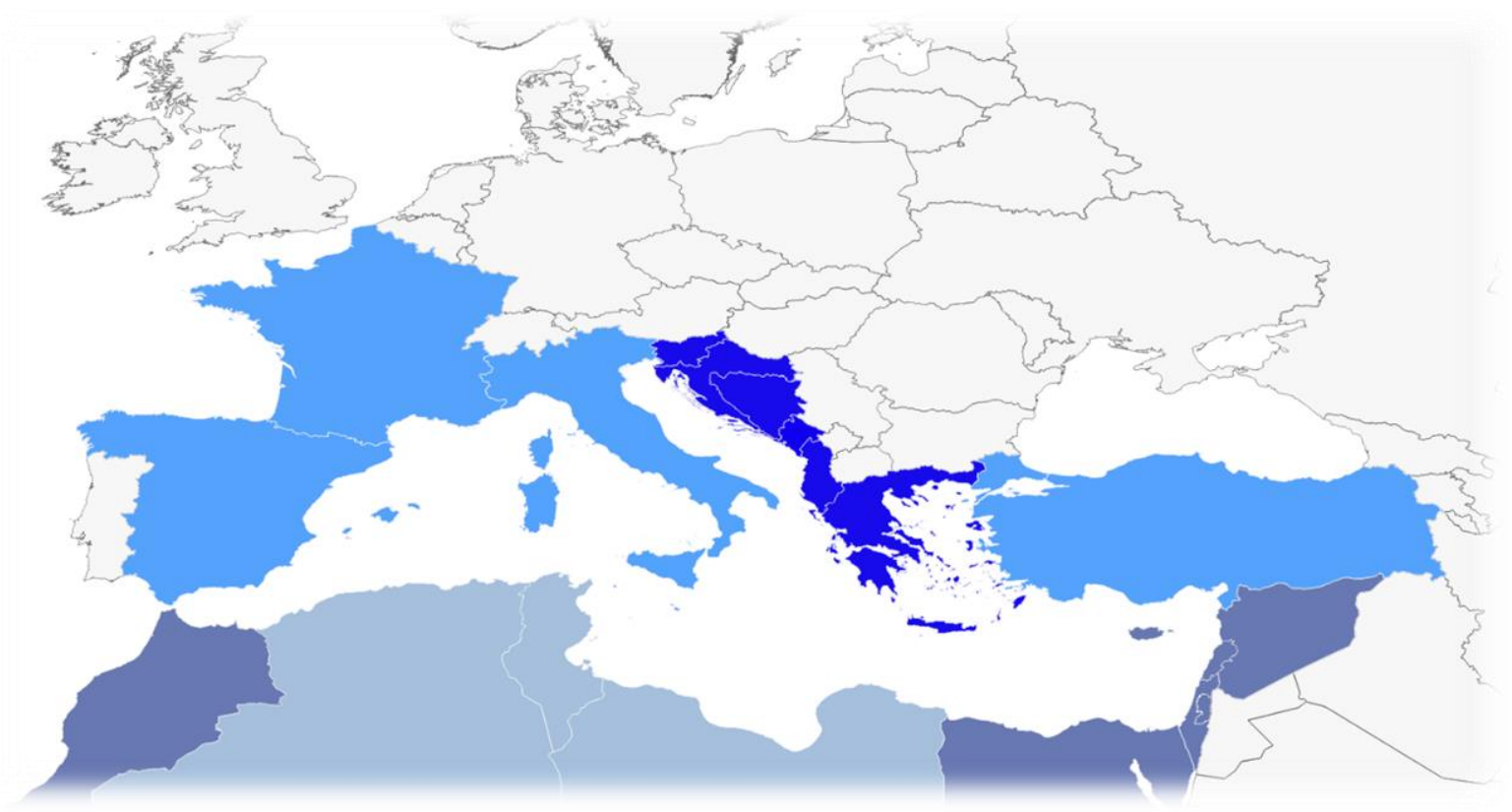

$>5,000 \mathrm{~m}^{3}$ capita $^{-1}$ year $^{-1}$ : Abundant water resources nationally, stress possible locally $1,700-5,000 \mathrm{~m}^{3}$ capita $^{-1}$ year $^{-1}$ : Occasional or local water stress

$1,000-1,700 \mathrm{~m}^{3}$ capita $^{-1}$ year $^{-1}$ : Water stress

$500-1,000 \mathrm{~m}^{3}$ capita $^{-1}$ year ${ }^{-1}$ : Chronic water scarcity

$<500 \mathrm{~m}^{3}$ capita $^{-1}$ year $^{-1}$ : Absolute water scarcity

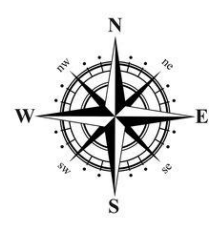

Fig. 4 

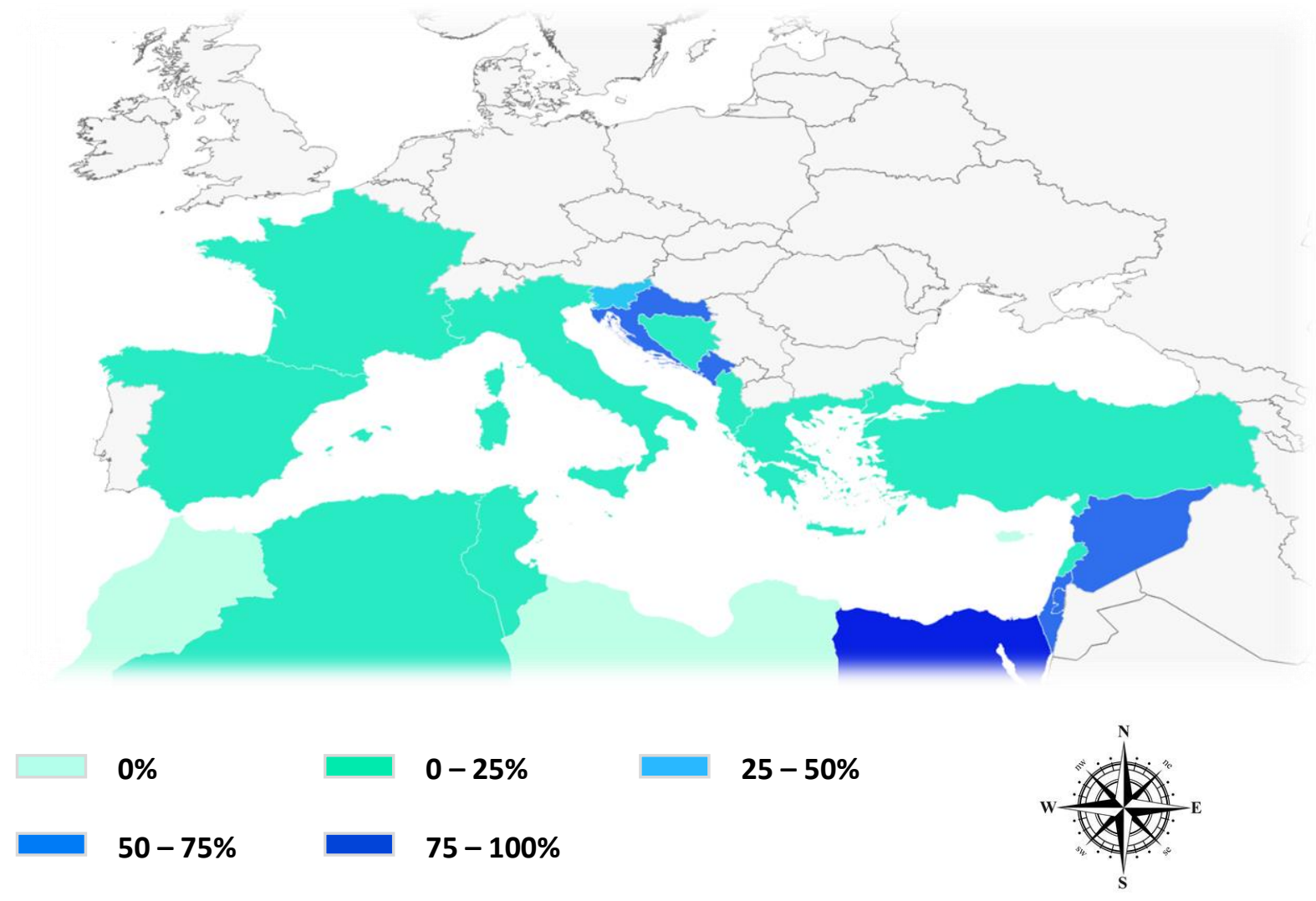

Fig. 5 